\title{
STUDENTS LEARNING PROBLEMS IN EARLY READING AND WRITING AT GRADE 1 OF ELEMENTARY SCHOOL
}

\author{
${ }^{1 *}$ Rosmayasari \\ ${ }^{1}$ SDN 101 Sukakarya, Dinas Pendidikan Kota Bandung, INDONESIA
}

Received 28 December 2020 - Revised 6 Agustus 2021 - Accepted 20 September 2021

\begin{abstract}
Characteristics of students who have learning difficulties are minimum IQ levels, tend to have lower academic self-esteem than able students, cannot be good listeners, think, speak, read and write, write spelling, and even calculate the calculation of natural mathematics. This research is a qualitative study with the participants of grade 1 students in an elementary school in Bandung. The focus of this research is on students' difficulty in reading and writing initially. The results of the study found a way to deal with students who have difficulty learning to read and write initially by connecting the initial knowledge students have with the material to be taught, structuring a comfortable environment for learning, using interesting resources, learning material and media, provide lessons for improvement or improvement, provide repetition of material or enrichment, provide learning motivation, and build good learning attitudes and habits. The involvement of parents in overcoming student learning difficulties is to be able to establish communication with class teachers to find out their children's learning development, provide free time with children to discuss lessons that have been given at school, provide learning facilities, understand children's learning difficulties and provide guidance, and provide motivation in learning.
\end{abstract}

Keywords: Difficulty reading, early writing, elementary school

\section{INTRODUCTION}

Elementary school (SD) as one of the basic educational institutions, has an important role in realizing the optimal growth and development of student potential. The Ministry of Education and Culture [1] explains that optimal development is not limited to achievement by following intellectual capacity, interests, and talents, but as a condition of development that allows students to be able to show healthy and responsible behavior and have good adaptation and socialization skills. Each student has different potentials and abilities, one of which is in terms of learning. Learning is an activity or a process to gain knowledge, improve skills, improve behavior, attitudes, and strengthen personality [2].

Learning has a very important role for students in gaining knowledge. said that learning takes place in the presence of two activities namely learning carried out by students and teachers who teach so that the goals of students who are learning can be achieved [3]. The success or failure of achieving educational goals depends a lot on how the learning process experienced by students as students [4]. At the elementary level, students need the readiness to follow the learning process. Because the long elementary school age range allows for various problems related to growth and development, individual differences in aspects of intelligence, personality, talents, interests, physical condition, family background, neighborhood, religion, tradition, customs, and culture. Learning difficulties are one of the problems associated with development. That is because the learning process experienced by students is not aligned with the expected development so that for some students may experience learning difficulties.

Learning difficulties or learning disabilities according to the National Joint Committee on Learning Disabilities is a general term for various groups of disorders that are characterized by great difficulties in learning and using the ability to hear, speak, read, write, reason, or count [5]. Difficulty learning as a condition experienced by students in their learning activities or lower than the achievements achieved by some classmates [6]. The state of students who cannot learn as they should is called learning difficulties [7]. Furthermore learning difficulties are a problem that is almost experienced by all students.

(C) 2021 by the authors; licensee PGSD UMP. This article is an open access article distributed under the terms and conditions of the Creative Commons Attribution License (http://creativecommons.org/licenses/by/4.0/). burosmayasari@gmail.com (*Correspondence) 
Various studies related to learning difficulties in elementary school, for example research on mathematics learning difficulties in elementary school [8], the results of students who show difficulties in learning mathematics also show difficulties in behaving such as emotional disturbances, discomfort, worry, irritability, aggressive attitude, disturbances in the thought process, everything makes learning activities interrupted. Research that explains that the learning model of mathematics, in particular, the calculation of multiplication with strategies/methods of playing, singing, and the use of fingers can help improve the ability of calculation/multiplication skills in children who have difficulty learning mathematics [9]. Factors influencing the social learning difficulties of elementary school students [10]. Difficulties in learning science in elementary school students [11]. Relationship between Family Social Support and Learning Difficulties. Study on Class V Students of Kemanggisan Elementary School 03 Morning [12]. Research on the level of learning difficulties, fields of study, causative factors, and the nature of learning difficulties of fifth-grade students at SD N Sosrowijayan, Yogyakarta [13]. Case study research on elementary / MI students in the city of Makassar about diagnostic learning difficulties in mathematics [14]. Case study analyzing students' learning difficulties in mental retardation at SDN Kedungputri 2 [15]. Factors that cause learning difficulties for students in Indonesian language class V SD Negeri 20 Meulaboh, West Aceh Regency 2015/2016 academic year [16]. Research on the development of science teaching materials in overcoming learning difficulties of fourth-grade students of SDN 63 Kota Bima [17]. Research on the difficulty of elementary school students on the subject matter grades of mathematics in grade I elementary school [18]. Research entitled the role of educators in overcoming the learning difficulties of students in SD Negeri 10 Banda Aceh [19]. Research on the analysis of learning difficulties of arithmetic operations in first-grade students of elementary schools [20].

The learning process of students with learning difficulties requires several strategies that are adapted to student conditions. Difficulty in reading, difficulty in writing expressions, and difficulties in the process of arithmetic are part of the learning difficulties in groups of academic achievement problems. Facts on the ground show that students who have difficulty learning in elementary school are almost entirely not well served. They still get the same treatment as regular students in general, meaning that the learning or educational services provided are the same as other students who have no difficulty learning in class. Basides, the knowledge of teachers in overcoming student learning difficulties are still many who do not know even wrong. This results in student achievement which shows a mismatch between potential and the achievement that is raised.

Based on observations during the learning process and interviews with class teachers conducted at a public elementary school in the city of Bandung, data obtained from students' learning difficulties obtained from student errors in doing assignments such as beginning reading and writing, students can not complete the task in accordance with the time allotted, slow in carrying out the tasks instructed by the teacher. Efforts that have been made by the teacher are limited to doing remedial and providing additional hours for students who have learning difficulties.

Learning difficulties is a condition experienced by students in conducting learning activities improperly due to threats, obstacles or disturbances related to internal and external factors that cause brain difficulties in following the normal learning process in terms of receiving, processing, and analyzing information obtained during learning [21], [22], [9], [23], [17].

Various studies related to learning difficulties in elementary schools, for example about the creativity of elementary school students who have difficulty learning to read in Kecamatan Ayah Kebumen Regency [24], learning to write for children with dysgraphia in primary schools. The results of his research explain that a positive attitude towards dysgraphic children can build motivation in children to learn to write [25]. Learning difficulties in speed reading [26]. Analysis of the difficulty of students in reading the beginning of the first grade of elementary school, the results are difficulties in reading the beginning of the first grade students of elementary school, namely: (1) have not been able to read diphthongs, double vowels, and double consonants, (2) have not been able to read sentences, (3) read choked up, (4) not yet able to say a few consonantal letters, (5) not yet able to spell, (6) reading carelessly, (7) quickly forgetting words that have been spelled, (8) adding and replacing words, (9) time spell long enough, and (10) have not been able to read thoroughly [27].

Based on the problems and phenomena that have been described above, the authors are interested in the study of literature on "Learning Difficulties in Elementary School Students". The problem examined in this paper is limited to the problem of learning difficulties in terms of reading the beginning and writing experienced by students in grade 1 in a public elementary school in the city of Bandung. Hopefully, it can provide benefits for various parties, both theoretically, namely to add wider insights about learning difficulties faced by elementary students. 


\section{MATERIAL AND METHODS}

This study uses a descriptive qualitative approach that is research used to examine natural object conditions, researchers as key instruments, data collection techniques with triangulation, data analysis is inductive with the results of research that emphasizes more meaning [28]. Researchers used a qualitative descriptive approach. The descriptive qualitative approach is a research method that aims to describe fully and deeply about social reality and various phenomena that occur in the community that is the subject of research so that they are described the characteristics, characters, traits, and models of these phenomena [3]. The location of this research is SDN 101 Sukakarya, Bandung City with 81 class 1 participants.

Data collection techniques used in this study were interviews, observation and document study. Research instruments in the form of interview and observation guidelines. The validation used is triangulation. Data analysis was carried out through three activities that run simultaneously. The three pathways are (1) data reduction, namely the process of selecting, focusing, paying attention to the simplification, abstracting, and transformation of rough data arising from written records in the field; (2) data presentation, which is the presentation of information that has been arranged which is likely to provide a conclusion and take action; and (3) conclusion drawing / verification, in this activity the researcher looks for the meaning of objects, records the order, and patterns from the beginning of data collection.

\section{RESULTS AND DISCUSSION}

Based on the results of observations and data collection conducted in class 1 in a public elementary school in the city of Bandung, of 81 students, 24 students have difficulty learning. The characteristics of students who experience learning difficulties including symptoms are experienced by all students including elementary students. In low-grade students (grades 1,2,3) who have learning difficulties, they are often shown to be slow in doing learning tasks. This is because low-grade elementary school students still need to adjust themselves after they have passed through education in kindergarten. This can be seen from their ability to participate in learning in a different class from other students [29]. The student has difficulty reading the beginning (how to sit naturally and well, the distance between the eyes and the book, how to hold the book, how to turn the pages of the book, eye movements from left to right, choose a place with bright light) and write the beginning (how to sit, how to hold a pencil, how to place a book, distance between eyes and book, hand movements up-down, left-right, flexing exercises with hand movements writing in the air/sand/table, relaxes fingers by coloring, tracing, drawing, making upright lines, italic, straight, and curved, tracing various shapes of images, circles, and letter-forming lines in brightly lit places). They are also still not memorized and cannot write letters of the alphabet and numbers, it is difficult to distinguish vowels and consonants, some letters and numbers are still confused, both pronunciation and writing such as the letter " $b$ " with " $\mathrm{d}$ ", writing the number "3" to " $\varepsilon$ ". Addition, they also have difficulty focusing (selective attention), inability to listen and speak even though they do not have hearing or speaking disorders, and difficulty concentrating in thinking, especially counting. As a result, students get low learning outcomes despite repeated remedial work.

Based on the findings above, the teacher needs to find alternative solutions, because in general students in grade 1 when they have been learning in class for 4 months already can read and write beginning and arithmetic. Therefore, diagnosis is carried out by identifying problems through observation, interviews, collaboration with parents, consolidation with the school to bring in experts both psychologists, psychiatrists, and doctors. Diagnosis is the determination of the type of problem or disorder by examining the background of the cause or by analyzing the symptoms that appear [7]. Difficulties can be interpreted as a certain condition that is marked by the obstacles in achieving the goal, so it requires even more active efforts to be able to overcome. Learning is defined as behavior. Diagnosis of learning difficulties is all activities undertaken by the teacher to find learning difficulties, determine the types of difficulties, the nature of learning difficulties, and also learn the factors that cause learning difficulties as well as how to determine and possibly overcome them either curatively (healing), or preventively (prevention) based on existing data and information ${ }^{30}$. Another definition of a diagnosis of learning difficulties is a process of trying to understand the types and characteristics and background of learning difficulties by gathering and using various data/information as completely and subjectively as possible so as to draw conclusions and decisions and look for alternative possible solutions [31].

At the observation stage, the teacher records all the things that students do (facial expressions, responses when given stimuli, attitudes, movements and actions that are done, speaking style and topics discussed both alone and with friends in class). The interview stage is first conducted with students who have learning difficulties, their classmates, classmates, other teachers who teach in the class and then the parents of the students concerned. From the results of observations and interviews, in collaboration with parents to consolidate the school to carry out psychological tests both individuals and groups, to obtain a picture of the potential intelligence of students who have learning difficulties (usually using WISC-R (Wechsler Intelligence Scale for Children-Revised). From the 
results of the psychological test it was found that students who have learning difficulties have an IQ of 90 - 125 as shown in Table 1 below:

Table 1. Psychological Test Results Viewed from the Age Range of Grade 1 Elementary School

\begin{tabular}{|c|c|c|c|c|c|}
\hline No & Student Code & Skor IQ & Class & Age (years) & School Origin \\
\hline 1 & DR & 125 & A & 7,1 & TK \\
\hline 2 & DEA & 125 & A & 6,9 & TK \\
\hline 3 & DAS & 120 & $\mathrm{~A}$ & 7,4 & PAUD \\
\hline 4 & $\mathrm{BP}$ & 115 & A & 7,1 & TK \\
\hline 5 & DPW & 98 & A & 7 & TK \\
\hline 6 & AAP & 90 & A & 6,10 & TK \\
\hline 7 & IB & 125 & $\mathrm{~B}$ & 7 & TK \\
\hline 8 & MR & 125 & B & 7,2 & TK \\
\hline 9 & MVFA & 120 & B & 7,3 & PAUD \\
\hline 10 & APFA & 118 & B & 7,1 & TK \\
\hline 11 & GAP & 100 & B & 7 & TK \\
\hline 12 & NS & 97 & B & 7 & PAUD \\
\hline 13 & STA & 125 & C & 6,5 & TK \\
\hline 14 & PON & 125 & $\mathrm{C}$ & 7,1 & TK \\
\hline 15 & Zak & 122 & $\mathrm{C}$ & 7,3 & TK \\
\hline 16 & NPK & 120 & $\mathrm{C}$ & 7,4 & TK \\
\hline 17 & MTP & 120 & $\mathrm{C}$ & 7,2 & TK \\
\hline 18 & QYS & 110 & $\mathrm{C}$ & 7 & TK \\
\hline 19 & MLP & 110 & $\mathrm{C}$ & 7 & TK \\
\hline 20 & $\mathrm{ADP}$ & 100 & $\mathrm{C}$ & 6,8 & TK \\
\hline 21 & $\mathrm{NN}$ & 98 & $\mathrm{C}$ & 6,9 & PAUD \\
\hline 22 & SA & 97 & $\mathrm{C}$ & 7,1 & TK \\
\hline 23 & SF & 90 & C & 7 & TK \\
\hline 24 & SS & 90 & C & 7 & TK \\
\hline
\end{tabular}

Based on the results of the psychological test results in Table 1 above, students who experience learning difficulties are at normal levels but have low academic achievement. Some characteristics of students who have learning disabilities are as follows normal or even gifted intelligence and the gap between intelligence and performance [5]. In connection with this Reid [32] expressed his opinion that learning difficulties usually cannot be identified until the child has failed in completing academic tasks that must be done. Learning difficulties like this can occur due to the allocation of less time for students to learn the predetermined subject matter. Each student will be able to complete the learning tasks if given enough time to learn [33]. Each material taught to students certainly has a different level of difficulty. So that each material requires a different amount of time to master it. This is caused by one of the principles of success in learning is repetition and practice. Repeating the lesson is one way to help the functioning of the memory. For this reason, in learning something you need repetition and practice many times so that it sticks in your memory so that it is not easily forgotten [34].

\section{DISCUSSION}

Students belonging to the classification of learning difficulties (specific learning disability) have the following characteristics: (1) Abnormalities that occur are related to psychological factors that interfere with fluency in language, when speaking, and writing; (2) In general they are unable to be good listeners, to think, to speak, read and write, spell letters, even mathematical calculations; (3) their low ability can be characterized through IQ test results or learning achievement tests especially abilities related to school activities; (4) Abnormal conditions can be caused by perceptual handicaps, brain injuries, minimal brain dysfunction, dyslexia, and developmental aphasia; (5) They are not classified as mentally retarded, mentally retarded, or those who are constrained by environmental, cultural or economic factors; and (6) Has special characteristics in the form of academic difficulties (cognitive difficulties), cognitive problems (cognitive problems), and social-emotional problems (social-emotional problems) [35].

Students also experience difficulty in reading and understanding conceptual matters. The process of learning to read in the beginning often experiences errors [36]. This is because the beginning grade students generally cannot read the writing or sound symbols well. Students find it difficult to arrange words into interesting sentences, especially when the teacher directs students to write and compose an essay. Therefore, students more often choose not to do it or only do it as short as possible. Thus, the objectives to be achieved from the learning process cannot 
be achieved. Difficulty reading in children is divided into two types, namely reading difficulties due to a genetic disorder and reading difficulties due to poor student reading ability (poor reading). Reading difficulties caused by genetic disorders usually occur in children with dyslexia while poor reading occurs in children who can read lower than normal reading skills [37].

Another difficulty experienced by students is developing the ideas they have. Some students have difficulty in conveying information verbally, so they cannot conduct presentations in front of the class or in front of other students. The teacher also states that the difficulties experienced in the form of difficulties in remembering the material taught, so that if the teacher asks again to fund the material taught by students as confused and unable to provide answers. Efforts made by the teacher before determining alternative solutions to the problem of student learning difficulties, namely it is recommended to first identify (efforts to recognize carefully) to the phenomena that indicate the possibility of learning difficulties that afflict the student. Some symptoms as indicators of learning difficulties in students are: (1) Showing low performance below the average achieved by the class group; (2) The results achieved are not balanced with the work done. He tried hard but his value was always low; (3) Slow in doing study tasks. He is always left behind by his friends in everything, for example in working on problems or in completing tasks; (4) Showing an attitude that is not reasonable, such as indifferent, pretending to lie and others; and (5) show different behavior. For example, irritability, moodiness, anger, confusion, frowning, lack of joy, and always sad [38].

The teacher's role is very important in the learning process. The teacher must also understand whether the learning objectives have been achieved. If not yet achieved the teacher must identify existing obstacles, one of which is about student learning difficulties. Elementary teachers are deemed necessary to be able to understand the knowledge and practice their abilities in serving students who have learning difficulties. The steps that can be taken by the teacher to overcome student learning difficulties are providing guidance and attention to students who have difficulty in learning, using learning media that can motivate students to learn, give assignments and exercises so that students want to learn independently, direct students to learn in groups, use interesting learning models and give awards to students so students feel happy and motivated in learning [19]. The teacher also links the material taught with daily life around students so that students easily understand the concepts being taught. Complementing the above statement, the classroom atmosphere does need to be planned and built in such a way by using appropriate learning models so that students can have the opportunity to interact with each other so that in turn optimal learning achievement can be obtained [39]. Other solutions that can be done by the teacher are making rules that are educative, advising, supervising, providing remedial teaching, providing personal guidance, looking for additional information in books that support, making effective use of media images in student books and teacher books and singing before starting the lesson to increase student morale [40].

\section{CONCLUSION}

Learning difficulties are a condition experienced by students in conducting learning activities improperly due to threats, obstacles or disturbances related to internal and external factors that cause brain difficulties in following the normal learning process in terms of receiving, processing, and analyzing information obtained during learning. Characteristics of students who experience learning difficulties are minimum IQ levels, tend to have lower academic self-esteem than students who are able, unable to be good listeners, to think, to speak, read and write, spell letters, even mathematical calculations.

The way to overcome students who have difficulty learning to read and write in the beginning is to connect the initial knowledge, students have with the material to be taught, structuring a comfortable environment for learning, using interesting sources, learning material and media, providing improved lessons or improvement, providing repetition of material or enrichment, providing motivation to learn, and building good attitudes and study habits. The involvement of parents in overcoming student learning difficulties is to be able to establish communication with class teachers to find out their children's learning development, provide free time with children to discuss lessons that have been given at school, provide learning facilities, understand children's learning difficulties and provide guidance, and provide motivation in learning.

Some suggestions that can be considered from the results of this study are the teacher and the school which is a second home for children to gain knowledge should continue to improve themselves by improving learning that is carried out in the classroom and provide suggestions that can support children with learning difficulties. The teacher can give additional time to teach students to read. Then the teacher gives a contact book and writes things that parents need to be taught at home so that there is a synergy between the teacher and parents of students. Parent involvement in overcoming student learning difficulties is to establish communication with class teachers to find out their child's learning development, provide free time with children to discuss lessons given at school, provide learning facilities, understand their learning difficulties and provide guidance, and provide motivation in the study. 


\section{REFERENCES}

[1]. Kemdikbud. Modul Pelatihan Kurikulum 2013. Sekolah Dasar /Madrasah Ibtidaiyah (SD/MI). Jakarta: Direktoran Pembinaan Sekolah Dasar. Dirjen Dikdasmen. Kemdikbud. 2018.

[2]. Suyono dan Hariyanto. Belajar dan Pembelajaran: Teori dan Konsep Dasar. Bandung: PT. Remaja Rosdakarya, 2012.

[3]. Sanjaya, W. Pembelajaran dalam Implementasi Kurikulum Berbasis Kompetensi. Jakarta: Kencana Prenada Media Group, 2005.

[4]. Slameto. Belajar dan Faktor-Faktor yang Mempengaruhinya. Jakarta: Rineka Cipta, 2003.

[5]. Slavin, R.E. Psikologi Pendidikan: Teori dan Praktik. Edisi Ke-9 Jilid 2. Jakarta: PT Indeks, 2011.

[6]. Sunartana. Evaluasi Pendidikan. Surabaya: Usaha Nasional, 2016.

[7]. Dalyono. M. Psikologi Pendidikan. Jakarta: PT Rineka Cipta, 2005.

[8]. Yeni, E.M. Kesulitan Belajar Matematika di Sekolah Dasar. Jurnal Pendidikan Dasar (JUPENDAS). 2015, $2(2), 1-$ 10.

[9]. Tarjiah, I. Pengembangan Model Pembelajaran Matematika bagi Siswa Berkesulitan Belajar di Sekolah Dasar Inklusi. Jurnal Ilmiah VISI PPTK PAUDNI. 2015, 10 (2), 102-113.

[10]. Rusmawan. Faktor yang Memengaruhi Kesulitan Belajar IPS Siswa Sekolah Dasar. Cakrawala Pendidikan, 2013, 32(2). 285-295.

[11]. Awang, I.S. Kesulitan Belajar IPA Peserta Didik Sekolah Dasar. Vox Edukasi, 2015, 6(2). 108-122.

[12]. Mora, L. Hubungan antara Dukungan Sosial Keluarga dengan Kesulitan Belajar. Studi Pada Siswa Kelas V SDN Kemanggisan 03 Pagi. Psychopedia. 2016, 1(1). 49-55.

[13]. Kusuma, A.D. Identifikasi Kesulitan Belajar Siswa Kelas V SD Negeri Sosrowijayan Kota Yogyakarta. Jurnal Pendidikan Guru Sekolah Dasar. 2016, 3(5). 169-182.

[14]. Nursalam. Diagnostik Kesulitan Belajar Matematika: Studi pada Siswa SD/MI di Kota Makassar. Lentera Pendidikan, 2016, 19(1), 1-15

[15]. Budiarti, M. dan Dewi, C. Analisis Kesulitan Belajar Siswa Mental Retardation di SDN Kedungputri 2 (Studi Kasus di SDN Kedungputri 2, Paron Kabupaten Ngawi). MUADDIB: Studi Kependidikan dan Keislaman. 2017, 7(2), 132-134.

[16]. Anzar, S.F. dan Mardhatillah. Analisis Kesulitan Belajar Siswa pada Pelajaran Bahasa Indonesia kelas V SD Negeri 20 Meulaboh Kabupaten Aceh Barat tahun ajaran 2015/2016. Bina Gogik, 2017, 4(1), 53-64.

[17]. Farida, F. Upaya Mengembangkan Bahan Ajar IPA dalam Mengatasi Kesulitan Belajar Siswa Kelas IV SDN 63 Kota Bima. Jurnal Pendidikan MIPA, 2017, 7(2), 131-138.

[18]. Selvianiresa, D. Kesulitan Siswa Sekolah Dasar pada Materi Nilai Tempat Mata Pelajaran Matematika di Kelas I SD. Jurnal Ilmiah Pendidikan Dasar. 2017, 2(1), 65-73.

[19]. Tusturi, R., Mahmud, H.R. dan Vitoria, L. Peran Pendidik Mengatasi Kesulitan Belajar Peserta didik di SD Negeri 10 Banda Aceh. Jurnal Ilmiah Pendidikan Guru Sekolah Dasar. 2017, 2(4), 127-132.

[20]. Suwarto. Analisis Kesulitan Belajar Operasi Hitung pada Siswa Kelas Satu Sekolah Dasar. Mosharafa: Jurnal Pendidikan Matematika. 2018, 7(2). 285-294.

[21]. Abdurrahman, M. Pendidikan bagi Anak Berkesulitan Belajar. Jakarta: PT. Rineka Cipta, 2003.

[22]. Sugihartono. Model Pembelajaran Inovatif serta Penerapannya pada SD/SMP CI-BI. Semarang: Rajawali, 2007.

[23]. Jamaris, M. Kesulitan Belajar: Perspektif, Asesmen, dan Penanggulangannya bagi Anak Usia Dini dan Usia Sekolah. Cetakan 2. Bogor: Penerbit Ghalia Indonesia, 2015.

[24]. Destri V. H. K. \& Nur'aeni. Kreativitas Siswa Sekolah Dasar yang Mengalami Kesulitan Belajar Membaca di Kecamatan Ayah Kabupaten Kebumen. PSYCHO IDEA, 2011, 9 (1). 52-62.

[25]. Suhartono. Pembelajaran Menulis untuk Anak Disgrafia di Sekolah Dasar. Transformatika, 2016, 12(1). $107-119$.

[26]. Januarti, N.K., Dibia, I.K., dan Widiana, I.W. Analisis Kesulitan Belajar dalam Pembelajaran Membaca Cepat Siswa Kelas V SD Gugus VI Kecamatan Abang. E-Journal PGSD Universitas Pendidikan Ganesha. 2016, 4(1), 110.

[27]. Pratiwi, R. 17 Cara Mengatasi Kesulitan Belajar Melalui Guru dan Orang tua. 2016, available online di https://www.halopsikolog.com/17-cara-mengatasi-kesulitan-belajar/119/. Accessed on 29 Oktober 2018, $09.24 \mathrm{pm}$.

[28]. Sugiyono. Metode Penelitian Kuantitatif, Kualitatif dan RED. Bandung: Alfabeta, 2016.

[29]. Samisih. Peran Guru Kelas dalam Menangani Kesulitan Belajar Siswa Sekolah Dasar melalui Layanan Bimbingan Belajar. Jurnal Ilmiah Mitra Swara Ganesha. 2014, 1(1). 58-68.

[30]. Purwanto, N. Psikologi Pendidikan. Bandung: PT. Remaja Rosdakarya, 2002. 
[31]. Ismail. Diagnosis Kesulitan Belajar Siswa dalam Pembelajaran Aktif di Sekolah. Jurnal Edukasi. 2016, 2(1), 3043.

[32]. Untari, E. Diagnosis Kesulitan Belajar Pokok Bahasan Pecahan Pada Siswa Kelas V Sekolah Dasar. Media Prestasi. Jurnal Ilmiah STKIP PGRI Ngawi. 2013, 13(1). 1-8.

[33]. Jamaris, M. Orientasi Baru dalam Psikologi Pendidikan. Bogor: Penerbit Ghalia Indonesia, 2010.

[34]. Dalyono. M. Psikologi Pendidikan. Jakarta: PT Rineka Cipta, 2005.

[35]. Delphie, B. Pembelajaran Anak Berkebutuhan Khusus dalam Setting Pendidikan Inklusi. Bandung: PT. Refika Aditama, 2006.

[36]. Petersen, et.al. Predicting Reading Difficulty in First Grade Using Dynamic Assesment of Decoding in Early Kindergarten: A Large-Scale Longitudinal Study. Journal of Learning Disabilities, 2016, 49(2), 200-215

[37]. Liu, Y.J. From Early Childhood Special Education to Special Education Resources Room Identification, Assessment, and Eligibility Determinations for English Language Learners with Reading Related Disabilities. Assessment for Effective Intervention, 2008, 33(3):177-187.

[38]. Djamarah, S. B. Psikologi Belajar. Jakarta: PT Rineka Cipta, 2002.

[39]. Harahap, L., dan Edy S. (2017). Development of Learning Media in Mathematics for Students with Special Needs. International Journal of Sciences: Basic and Applied Research (IJSBAR). 2017, 33 (3), 1-12.

[40]. Manalu, R., Meter, I.G. \& Negara, I.G.A.O. Analisis Kesulitan-kesulitan Belajar IPA Siswa Kelas IV dalam Implementasi Kurikulum 2013 di SD Piloting Se-Kabupaten Gianyar. e-Journal PGSD Universitas Pendidikan Ganesha. 2016, 3(1).

*) The author is a doctoral student in Elementary Education, Postgraduate School of Universitas Pendidikan Indonesia.

\section{http://jurnalnasional.ump/index.php/dinamika}

